\title{
Construction of Female Awareness and Discourse Authority : Interpretation of Palace of Desire from the Perspective of Feminist Narratology
}

\author{
Fang Manfeng \\ Institute of Foreign Language and Culture, Guangdong University of Foreign Studies, Guangzhou, \\ Guangdong, China \\ 2959176902@qq.com
}

Keywords: Palace of Desire, Feminist Stylistics, Narrative Voice

\begin{abstract}
Palace of Desire is an excellent costume TV series directed by Li Shaohong. There are two screenwriters named Zhen Chong and Wang Yao. They used unique writing strategies to narrate the story of Princess Tai Ping and Empress Wu Zetian who are trapped in a delimma of power and emotion during a special period of Tang Dynasty, showing the confusion of women in the feudal society of ancient China. This article will use the theory of feminist stylistics to analyze the script of Palace of Desire. To be more specific, the paper focuses on narrative voices in Palace of Desire. It is hoped that how the screenwriters construct the narrative authority of women and make the work a feminist classic can be interpreted.
\end{abstract}

\section{Introduction}

Palace of Desire is one of the masterpieces of Li Shaohong, a well-known Chinese female director. It is premiered on March 30, 2000 and receives great popularity after the broadcast. The script version of Palace of Desire is published by People's Literature Publishing House in the same year. With beautiful and intriguing language, it retains the original flavor of the dialogue of the characters in the TV series. The book revolves around the story of several important historical figures in the $\mathrm{Wu}$ Zetian period of the Tang Dynasty and fully demonstrates the complicated relationship of power and emotion about women at that time who have much difficulties in realizing their self-value under the feudal patriarchal system. Princess Taiping grows up innocently under the protection of her mother Wu Zetian, but finally went to disillusionment after experiencing four failed relationships. She is the representative of women's emotion. However, Wu Zetian is bold to break the constraints of feudal patriarchal society, pursuing unlimited power and Prince Taiping's understanding for her whole life. She is the symbol of women's power. And there are a great number of other brilliant and attractive women in this opera. All of them are struggling for power and love. Indeed, what the play wants to express is that it is a dilemma for a woman whether power and emotion can coexist and how to make a balance between them.

Since it is a well-received Chinese costume opera, it has attracted much attention from domestic researchers. Most of the researches are about its aesthetics, such as its poetic dialogues, beautiful 
clothes, music, its unique characterization skills. Some researchers study the narrative strategies in this opera from the perspective of the narrative space and narrative focalization. And even a few of them take heed of the feminist elements, but they are not as critical as they only introduce and analyze the women characters from their languages and clothes without a consistent theory in their papers. Moreover, little critical attention has been paid to the feminist narrative voices in it.

The American scholar Susan Sniader Lancer took the lead in combining feminist literary criticism that is emerged in the 1960s with classical structural stylistics in 1981 and published a article "Toward a Feminist Narratology" in the magazine Style. In the article, the concept of "Feminist Narratology" is proposed for the first time. (Shen \& Wang 196)Having absorbed the ideology and standpoint of feminist literary criticism, feminist narratology combines textual analysis with the context interpretation and analyzes what and how gender politics are embodied in the narrative structures and strategies in the work. Being a new interdisciplinary research paradigm, it not only provides a new perspective for the development of feminist literary criticism, but also enriches narratology.

As is introduced above, Palace of Desire can be seen a panorama of struggling women. Therefore, it is significant to apply the feminist narratology to study how female awareness and discourse authority are constructed in this play.

\section{Narrative Voice}

In narratology, "voice" refers to "the voice of various types of narrators telling stories". (Shen 138)In the long history of literature, men dominate the discourse with their authority, while women are neglected in a marginal position of discourse and forced to passive "aphasia", and it has become a power struggle for the hero and heroine in a novel to determine who is the narrator, who is the narrated and what is narrated, which is exactly the manifestation of the social struggle between men and women." (Shen\&Han 298)Therefore, Feminist Narratology "combines technical interpretation of narrative voice with feminist political interpretation, studying the social nature and political significance of narrative voice." (Shen 142)By analyzing the text of the work, it explores the social and historical factors behind the literary phenomenon and digs out the writer's female consciousness. In Fictions of Authority: Female Writers and Narrative Voices, Susan Sniader Lancer divides the narrative voices into three types, namely, authorial voice, personal voice and communal voice. (17) In the script of Palace of Desire, the two screenwriters skillfully use these three kinds of narrative voices to make female voice in a feudal patriarchal society heard.

\subsection{Authorial voice: Emphasis on Female Images}

Authorial voice is "the voice of hetero-diegetic narrator which is both collective and selfsignified.” (Lancer 17) In this narrative mode, the narrator, as a bystander, exists outside the time of narration and does not live in the imaginary world of the work at all.( Lancer 18) He can not only control the whole text, gain insight into the characters' hearts, but also express their opinions and make evaluations about the events and characters in the text. Therefore, it has an advantage over other narrative modes and carries much more authority. As Palace of Desire is a long script of 685 pages, there are naturally many scene transitions between different acts and descriptions of the expression, psychology and actions of characters. These all depend on the authorial voice of the two screenwriters. "Finally, she opens her eyes, looking around the dull eunuch standing straight. Gradually she returns to her normal dignity and strictness. Then she gets up.”(Zheng\& Wang 8)In this brief scene transition, the actions of Wu Zetian after the nightmare are so vivid. Through the detailed action descriptions created by the screenwriters' voice, readers can see the psychological activities in her mind. At first, she is a bit nervous and terrified from the evil dream. Then she calms 
down and finds herself in the reality. A woman with a tough heart comes into life immediately.

As the omnipotent third-party narrator, the screenwriters also control the fate of each character with their authorial voice. In this book, great efforts are made to highlight the image and status of women. Princess Taiping, Empress Wu Zetian, Miss He Lan, Mrs. Wei and other female characters are all portrayed as women with exceedingly excellent qualities such as strength, intelligence, and courage, while most of male characters are inferred to be weak, stupid and cruel. And surprisingly, the screenwriters seem to spill so much more ink on the life of women that men are neglected to some extent. And there is no man acting from beginning to end in their pens. "(Along with the side narration) under the water, the exquisitely beautiful dress of Miss He Lan is flowering as lily with her hair flowing. She is just like a goddess in the dream, beautiful but ominous"(Zheng\& Wang 133)When describing the death of Miss He Lan, the two screenwriters still focus on the beauty of a woman using genteel metaphors. By contrast, when Princess Taiping's second husband Wu Yousi dies, they make comments like this, "His death is without honor, just like his birth, his marriage and everything about him. He is just a clumsy farmer and becomes the sacrifice of political struggles between Princess Taiping and Emperor Wu Zeitian unintentionally. He is slow but stubborn, so he blindly convinces himself that he is no longer a farmer, which is just his tragedy, a tragedy about a sincere but menial man.' (450)Through the tongue of the screenwriters, Wu Yousi is a bitterly mean man who tries to manipulate Princess Taiping but fails. There are a plenty of such obvious contrasting depictions about men and women in this play. What the screenwriters want to emphasize is that women can also stand in a foregrounding stage with men as the mere background, which challenges the tradition of the feudal patriarchal society.This is the obvious advantage of authorial voice in Palace of Desire. It can arrange reasonable and interesting plots to outline a group of shining women images in the feudal patriarchal society of ancient China and express female awareness directly with the tongue of the screenwriters.

\subsection{Personal voice: Witness of Family Tragedy and Female Tragedies}

Personal voice mainly uses the perspective of the first person "I" to talk about the story of the "I".(Lancer 20)In Palace of Desire, there is a monologue at the beginning of most episodes, which leads readers to find out that the main narrator of the whole script is actually Elder Princess Taiping. And she recalls the whole stories about herself and other people around her in the hope of sharing them with her niece Li Longji.These brief and incisive monologues are both a summary of Taiping's life experience and the externalization of Princess Tai Ping's own inner world. Princess Taiping uses her eyes which are full of humanity and emotion to pay attention to the destiny of each family member and presents a colorful picture of different kinds of personality to readers with her own subjective understanding. "According to your grandmother, when I was born, the city of Chang'an was raining heavily and unstoppedly. Months of heavy rain soaked the Da Ming Palace as if it had lost the foundation.Even people's facial expressions seemed bitter and upset as they had not seen sunshine for several days.Based on the theory of a fortune-teller, it was the symbol of Yin, indicating the birth of a Princess of the Tang Dynasty. "(Zheng\&Wang 1)The first monologue uttered by Princess Taiping at the beginning of the play not only briefly introduces the main character, location, background and time of the story, but also sets the mood and atmosphere of the whole play. And then she recalls and narrates great events about that dynasty by a form of storytelling. In some of the events, she is the main figure, while in others, she is merely a witness. From personal voice, readers can see that Princess Tai Ping is a courageous, charming and smart woman who value love more than power. As the major figure of four unfruitful relationships, Princess Taiping is a tragic woman who can not get true and innocent love in her whole life. She loves Xue Shao but he finally committed suicide. She gets married to Wu Yousi to rebell against 
her mother but did not obtain the happiness of marriage. After being deceived by Zhang Yizhi, she kills him for revenge. And finding out her niece Li Longji falls in love with her, she chooses to commit suicide to stabilize the whole country. In the end, she becomes totally disillusioned and says" I have come to realize that I have always longed for death. T know so much about the rules of the whole world that it lost all the sense of beauty of my eyes."(Zheng\&Wang 685) As a witness of the Tang Dynasty, Princess Taiping sees how the men of Li family were ruined by power. "Prince Xian is finally exempted from the crown, and it is done very disgracefully. He used to be convinced in his own talent and courage so passionately and stick to his own ambition and goal. However, he can never get away with the doom of being destroyed psychically and mentally."(Zheng\&Wang 255)Here Princess Taiping expresses her sympathy for the failure of her brother Prince Xian.

In this tough struggling-for-power process, one of the most important figures is her mother $\mathrm{Wu}$ Zetian. In a conversation between Princess Taiping and Wu Zetian, two sides of personality of Wu Zetian are exhibited directly in the voice of Taiping. One the one hand, Wu Zetian is a cold-hearted empress who loves power more than anything. "Wu Zetian: I do not like how you look at me. It seems that you blame me for my obsession with power. Well, I tell you what. I am crazy for power. I am afraid of losing power........Taiping: If that's so, you will lose more.”((Zheng\&Wang 380-381) Here, Prince Taiping tells readers how Empress Wu Zetian desires for power in a dialogue with her mother. On the other hand, she is also a lonely fighter who controls the male-dominated country. "Taiping: But you are a woman. All the man are against women becoming the Empress. There has been so much blood. (Zheng\&Wang 381) From this, Prince Taiping expresses her worries and respect for her mother. Because the main narrative voice inside the story is Princess Taiping's personal voice and she cares so much about the relationship about her mother, it seems that she mainly focuses on talking about the changes in her complicated relationship with Wu Zetian. As women with great authority, they are both trapped in the struggle of power and love. Politically, they have to fight against all the ambitious male figures. Emotionally, they can not enjoy love just like ordinary people. Through the personal voice of Princess Taiping, readers can see two outstanding women who have much courage to challenge male power of feudal system and win female authority in the patriarchal society.

\subsection{Communal Voice:Endless Pursuit of Power}

Communal voice is a unique phenomenon in a female narrative text, by which groups asking for the right to speak are given narrative authority. "Through multidimensional and interactively empowered narrative voice, or through the voice of an individual who has been clearly authorized by the group to express themselves is fixed with words in the text." (Lancer 22)Lancer distinguishes three different communal voices: "The 'monophonic' form of a narrator speaking on behalf of a certain group, the 'co-speaking' form of the plural subject 'we' and the 'rotational' form in which individuals in the group speak in turn.”(23)In Palace of Desire, these three kinds of communal voices are prevalent. Like Empress Wu Zetian, she is a great representative of women who understand the difficulties of them. "Remember, in the Da Ming Palace, including the magnificent Tang Dynasty, only men are masters. However, as a woman, especially a woman who can not tolerate loneliness and has great ambition, she cannot live freely in this world. ” (Zheng \&Wang 98) the two lines clearly show how difficult a woman wants to stand out in a patriarch society. However, she also understands the importance of independence and strenuousness by citing a metaphor "you must grow your own leaves, grow hard like a real tree" (98). On behalf of all the outstanding women at that times, her voice states the brutality of women's live and their hard choices. No wonder that Mrs Wei says "It is uncertain whether she (referring to Empress Wu Zetian is the only one or not. Taiping, I have always dreaming about a chance to compete with the princes on talents, 
but I never have. Now, I have earned myself this honor! ” (Zheng \&Wang 617) when Taiping criticizes her of controlling too much power. Mrs Wei considers Empress Wu Zetian as her example. They have the same experience of being isolated and banished, so they make up their mind to compete with men for power. Even the seemingly carefree Prince Taiping sometimes expresses her awe and desire for power in her monologue. "Power, indeed. It is the first time in my life that I feel about power so straightforward. It is a mysterious and attractive feeling..........Power, you are an eternal topic in my life, you are untouched god's imprint hidden behind your royal blood!" (Zheng \&Wang 127)Just like her mother, she likes the happiness brought about by power. As a result, she forcefully gets involved in political struggles afterwards. It can be said that the endless pursuit of power is an everlasting element in the communal voice in this play.

\section{Conclusion}

In conclusion, Palace of Desire is an excellent costume script which reveals the power-love dilemma of several outstanding women in the feudal patriarchal society from a female standpoint. In this play, the two screenwriters use a unique feminist narrative strategy to allow women to control the narrative of the book, to express dissatisfaction and doubts about the patriarchal society. There are three kinds of narrative voices operating together to construct female awareness and discourse authority, namely, authorial voice, personal voice as well as communal voice. By authorial voice, a great number of shining female images are emphasized and praised. By personal voice, Princess Taiping acts an authentic witness to show how Li family dominated by men is gradually by ambitious women and to show how a woman tackles her personal tragedy in a patriarch society. And by communal voice, the topic of pursuing endless power is highlighted in the women group who tries to reinforce their discourse authority. The three feminist narrative voices combined lead readers to think about the ways how women stand out in a male-dominated society and how they get out the dilemma of love and power. In this play, while affirming the value of women's life and demonstrating the consciousness of women's subjectivity, the two screenwriters have also successfully constructed female awareness and narrative authority.

\section{References}

[1] Lanser,S.(1992)Fictions of Authority:Women Writers and Narrative Voice.Cornell University Press.

[2] Lanser, S.(1986)Toward a Feminist Narratology.Style (3):341-63.

[3] Shen D.(2004) Narrative Form and Gender Politics:On Feminist Narratology. Journal of Peking University

(2):136-46.

[4] Shen D. and Hang J.M. (2005) Narrative Theories in English Novels.Peking University Press.

[5] Zheng C. and Wang Y.(2000) Palace of Desire. People's Literature Publishing House. 